Acta regionalia et environmentalica 2

Nitra, Slovaca Universitas Agriculturae Nitriae, 2013, p. 46-50

\title{
WOOD ASH FERTILIZATION OF ENERGY PLANT BASKET WILLOW (SALIX VIMINALIS L.)
}

\author{
Pavol OTEPKA, Miroslav HABÁN
}

Slovak University of Agriculture in Nitra, Slovakia

\begin{abstract}
Energetic utilization of wood biomass obtained from fast-growing woody plants nowadays records more important capability. The article discusses the issue of research using wood ash as a solid waste from the boiler while burning biomass and the intensification of short-rotation coppice basket willow - common osier (Salix viminalis L.) for energy use as a renewable energy source. The purpose of the article is to show the importance of basket willow (Salix viminalis L.) as a short-rotation coppice with the emphasis of its production and remedial effects. The examined varieties of willow can be ordered according to their suitability for the conditions

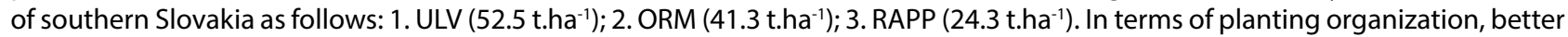
results were achieved in planting space $B$ in single rows (41.8 t.ha-1) than in planting space $A$ as double row system (36.9 t.ha-1 $)$. According to the Slovak Republic legislation, it is allowed to use wood ash only for the scientific purposes. We assume that the results obtained within this project will be applied in the modification of legislative framework to enable the use of wood ash for applying nutrients at least in energetic plants cultivation.
\end{abstract}

Keywords: renewable energy resources (carriers), biomass, short-rotation trees, basket willow, common osier (Salix viminalis L.), wood ash

The issue of renewable energy resources is still increasing, especially in times when oil crisis and negative consequences of global climate change have been appearing more and more often in the human society. One of these resources is biomass. It fulfils majority of benefits from all the spectrum of renewable energy resources (Húska et al., 2000; Niňaj a Húska, 2005). In the spring of 1994, experiments to prove the possibility for cultivation of fast-growing varieties of basket willow - common osier (Salix viminalis L.) were carried out in Krivá research centre, located in the Orava region of the Slovak Republic. For this purpose, three varieties of willow bred at the Research Institute of Agriculture in Svalöv (Sweden), were used: ULV, ORM and RAPP (Habovštiak a Daniel, 2001). The same varieties are tested in the conditions of warm agro-climatic region in Dolná Malanta, Nitra, Slovakia. They have been grown here continuously since 1996 . The experiments are established on Experimental Base of the Slovak University of Agriculture in Nitra, Slovak Republic (Otepka a Habán, 2006; Otepka a Habán, 2011; Habán, Otepka a Boroš, 2013).

By the cultivation of fast growing tree coppice with short rotation period, the nutrients for growing plants take off intensively, reducing their storages in soil. Partial compensation might be mineral multicomponent fertilization, for which wood ash with the content of wide spectrum of macro and microelements can fit well. The specific problem is that this type of solid waste generated in the boilers does not contain nitrogen, which had been released into the air after the biomass was burned.

\section{Material and methods}

Methodology of the experiment with wood species basket willow - common osier (Salix viminalis L.) has a long-term design ( 25 years). The stand was established by planting in the spring of $1996\left(19^{\text {th }}\right.$ April). The planting material was originated from Swedish breeding (Svalöv); the planting material was obtained in Research Centre Krivá in the Orava region, the Slovak Republic (VÚTPaHP). Planting of cuttings were done in length $0.20 \mathrm{~m}$; thickness from 10 to $20 \mathrm{~mm}$. Forecrop was Amaranthus sp. Soil preparation was done by plowing to the depth of $30 \mathrm{~cm}$, after that dragging and harrowing were performed. Planting method: manually by hands. Treatment during the vegetation period is aimed at regulation of harmful factors (weeds, pests and diseases) and maintaining the status and condition of the crop stand.

The total cultivation area is approximately $648 \mathrm{~m}^{2}$; area of individual plots (variants) is $108 \mathrm{~m}^{2}$; total number of tested plots is 6; identification of plots: ORM/A, ORM/B, ULV/A, ULV/B, RAPP/A RAPP/B. Cultivated varieties: ORM, ULV, RAPP. Design of experiment: A - Double row planting with row distance $=0.5 \mathrm{~m}$, alternated $1.25 \mathrm{~m}$ and $0.75 \mathrm{~m}$ between rows, $B-$ plant spacing $0.5 \times 0.75 \mathrm{~m}$. The article includes results from a fourth four-year harvesting period of willow in the presented locality (2008-2011). In this plantation, the crop biomass forecasting of willow is based on mathematical-statistical model, published by Špánik and Čimo (2009). Wood ash from clean, chemically non-treated wood from heating plant in Hriňová was applied in the autumn period (October 2009) and in the spring period (March 2010) in doses of 1.0, 3.0 and 5.0 t.ha $^{-1}$, while the control area was left without application of wood ash. Size of each area is: $2 \times 162 \mathrm{~m}^{2}$, i.e. $324 \mathrm{~m}^{2}$.

During the whole period of the project there were carried out samplings of plant material for analysis of selected substances suitable for monitoring changes in its content during the period of application of wood ash on the plantation. The samples were taken from cultivated varieties of willows before leaf fall just before the application of wood 
ash. In this biological material there were monitored these parameters, resp. contents of: $\mathrm{N}_{\mathrm{t}^{\prime}} \mathrm{P}, \mathrm{K}, \mathrm{Ca}, \mathrm{Mg}, \mathrm{Mn}, \mathrm{Zn}, \mathrm{Cu}, \mathrm{Fe}$, $\mathrm{Na}, \mathrm{S}, \mathrm{Pb}, \mathrm{Cd}, \mathrm{Ag}, \mathrm{As}, \mathrm{pH}$ and dry matter content. The samples of plant material were collected as a one year shoots of plants before leafs fall in autumn. At this time and in these parts of plants, the content of monitored parameters is the most proved and the most affected by the technology of cultivation. According to the proposed design of the experiment, there were taken samples of soil in the autumn and in the spring in which there was carried out the analysis of $\mathrm{N}_{\mathrm{an}}, \mathrm{N}, \mathrm{P}, \mathrm{K}, \mathrm{Mn}, \mathrm{Zn}, \mathrm{Cu}, \mathrm{Fe}, \mathrm{Na}, \mathrm{S}, \mathrm{Pb}, \mathrm{Cd}, \mathrm{Ag}, \mathrm{As}, \mathrm{pH}$, humus and solid contents.

The results of the analysis based on initial condition of soil and plants before the application of wood ash and subsequent analysis performed in other periods showed changes in contents of parameters depending on the effect of fertilization of the stand by wood ash and agroecosystem responses to this fertilization.

\section{Results and discussion}

Number of individual willow plants (Salix viminalis L.) per unit area depends on the plant spacing of 2.00 individual plants per $\mathrm{m}^{2}$ (planting space A) or 2.67 individual plants per $\mathrm{m}^{2}$ (planting space B). According to Šimala - Habovštiak
(1995), well-managed willow grows in the first year up to the height of 2.0-3.0 m and after the fourth year of cultivation, the crop is $7.0 \mathrm{~m}$ high. Individual crops with height of $7.0 \mathrm{~m}$ can be harvested. From this finding it is difficult to conclude whether the authors considered these data also in assessing of the third harvest period, but for the comparison of results we indicate that one year after the second harvest, the indicated height of all three varieties was not reached: ORM (1.70 m), ULV (1.77 m) and also variety RAPP (1.45 m, see Table 1) was below the height of $2.00 \mathrm{~m}$. Better average height of rods was always reached at the plant spacing $B$, i.e. the one where denser planting was applied. In subsequent years, the height of the vegetation ranged from $1.95 \mathrm{~m}$ (variety, RAPP/A, in the $10^{\text {th }}$ year after planting) to $4.27 \mathrm{~m}$ (variety ULV/B, in the $12^{\text {th }}$ year after planting), and as it can be seen in Table 1, in neither of the cases the height reached $7.0 \mathrm{~m}$. This we attribute to the impact of harmful agents, soil characteristics of the experimental unit as well as to the weather conditions during the period of observation. When observing an average rod thickness, the values were measured according to the forestry parameters i.e. at a level of $1.3 \mathrm{~m}$ above the soil surface. Based on observations in the second harvest period, in this parameter we reached relatively low values, since in neither of the cases the value got over $20 \mathrm{~mm}$. For ULV variety grown in the plant spacing $\mathrm{B}$, the highest average rod thickness observed was $18.2 \mathrm{~mm}$.

Table 1 Measured parameters of basket willow - common osier (Salix viminalis L.) during four-year period (2008-2011)

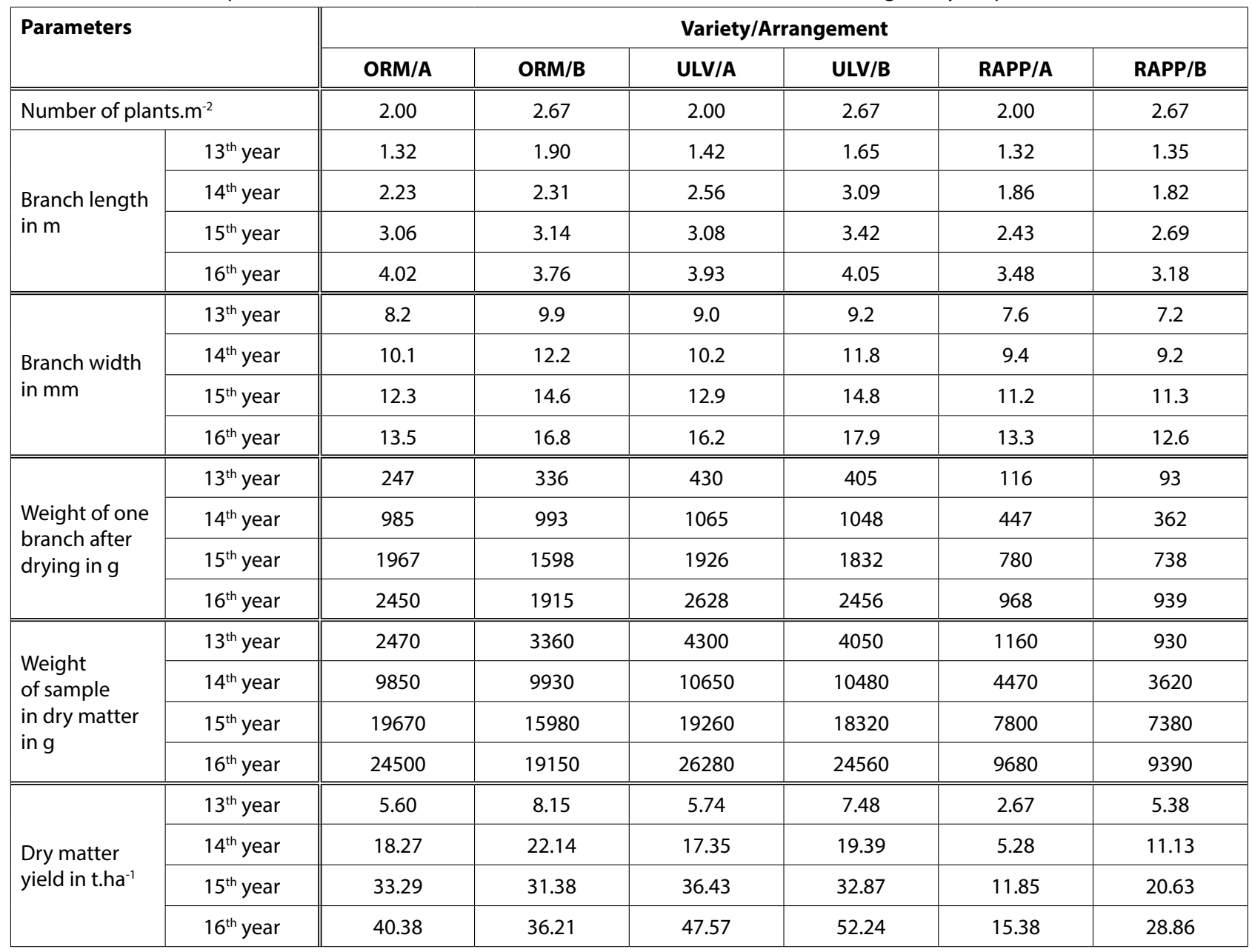


Table 2 The results of laboratory analysis of aboveground basket willow biomass (Salix viminalis L.) fertilized by wood ash in mg.kg-1

\begin{tabular}{|l||c|c|c|c|c|c|c|}
\hline Year & Indicator & $\mathbf{N}$ & $\mathbf{P}$ & $\mathbf{K}$ & $\mathbf{~ C a}$ & $\mathbf{M g}$ \\
\hline \hline \multirow{2}{*}{2009} & average & 17756.3 & 1915.0 & 5750.0 & 18213.0 & 3357.2 & 832.1 \\
\cline { 2 - 8 } & standard deviation & 2063.9 & 155.7 & 1581.1 & 3684.9 & 561.1 & 134.2 \\
\hline \multirow{2}{*}{2010} & average & 14883.5 & 2159.2 & 7104.2 & 16187.9 & 2123.0 & 288.3 \\
\cline { 2 - 8 } & standard deviation & 1132.5 & 257.5 & 1127.1 & 215.8 & 497.8 & 50.8 \\
\hline
\end{tabular}

\begin{tabular}{|l||c|c|c|c|c|c|}
\hline \multirow{2}{*}{ Year } & Indicator & $\mathbf{S}$ & $\mathbf{F e}$ & $\mathbf{M n}$ & $\mathbf{Z n}$ & $\mathbf{C u}$ \\
\hline \hline \multirow{2}{*}{2009} & average & 2375.8 & 168.4 & 93.6 & 92.1 & 6.1 \\
\cline { 2 - 8 } & standard deviation & 695.0 & 35.9 & 19.6 & 24.5 & 1.0 \\
\hline \multirow{2}{*}{2010} & average & 1969.2 & 202.5 & 203.9 & 114.3 & 6.8 \\
\cline { 2 - 8 } & standard deviation & 480.8 & 71.3 & 84.6 & 22.1 & 0.8 \\
\hline
\end{tabular}

\begin{tabular}{|l||c|c|c|c|c|c|}
\hline Year & Indicator & Co & $\mathbf{N i}$ & $\mathbf{C r}$ & $\mathbf{P b}$ & $\mathbf{C d}$ \\
\hline \hline \multirow{2}{*}{2009} & average & 1.9 & 5.2 & 1.4 & 2.2 & 0.7 \\
\cline { 2 - 7 } & standard deviation & 0.4 & 1.0 & 0.2 & 0.6 & 0.1 \\
\hline \multirow{2}{*}{2010} & average & 1.8 & 4.1 & 1.2 & 1.7 & 0.5 \\
\cline { 2 - 7 } & standard deviation & 0.2 & 0.6 & 0.3 & 0.2 & 0.1 \\
\hline
\end{tabular}

Table 3 The results of laboratory analysis of soil under canopy of basket willow (Salix viminalis L.) fertilized by wood ash in mg.kg-1

\begin{tabular}{|l||c|c|c|c|c|c|c|}
\hline Year & Indicator & $\mathbf{N}_{\text {an }}$ & $\mathbf{N}^{-} \mathbf{N O}_{\mathbf{3}}^{-}$ & $\mathbf{N}^{-} \mathbf{N H}_{4}^{+}$ & $\mathbf{N}$ & $\mathbf{P}$ & $\mathbf{K}$ \\
\hline \hline \multirow{2}{*}{ Autumn 2009 } & average & 12.0 & 1.8 & 10.2 & 1421.4 & 54.2 & 369.8 \\
\cline { 2 - 9 } & standard deviation & 20.3 & 2.2 & 19.7 & 289.8 & 25.6 & 88.3 \\
\hline \multirow{2}{*}{ Spring 2010 } & average & 6.8 & 3.0 & 3.8 & 1460.7 & 52.4 & 301.0 \\
\cline { 2 - 9 } & standard deviation & 4.2 & 4.0 & 1.2 & 273.3 & 23.3 & 34.4 \\
\hline \multirow{2}{*}{ Autumn 2010 } & average & 6.3 & 0.4 & 6.7 & 917.8 & 46.4 & 327.1 \\
\cline { 2 - 9 } & standard deviation & 9.4 & 1.3 & 10.6 & 181.6 & 20.6 & 46.5 \\
\hline
\end{tabular}

\begin{tabular}{|l||c|c|c|c|c|c|c|c|}
\hline \multirow{2}{*}{ Year } & Indicator & Mg & $\mathbf{C a}$ & $\mathbf{N a}$ & $\mathbf{F e}$ & $\mathbf{M n}$ & $\mathbf{Z n}$ & $\mathbf{C u}$ \\
\hline \hline \multirow{2}{*}{ Autumn 2009 } & average & 267.4 & 5200.1 & 35.3 & 6.8 & 4.4 & 0.9 & 1.1 \\
\cline { 2 - 10 } & standard deviation & 54.5 & 2418.3 & 6.3 & 4.9 & 1.7 & 0.3 & 0.3 \\
\hline \multirow{2}{*}{ Spring 2010 } & average & 277.9 & 4579.8 & 29.2 & 6.1 & 3.5 & 0.6 & 0.9 \\
\cline { 2 - 11 } & standard deviation & 47.5 & 1519.3 & 7.6 & 4.0 & 1.7 & 0.3 & 0.2 \\
\hline \multirow{2}{*}{ Autumn 2010 } & average & 243.1 & 3335.4 & 34.4 & 4.0 & 3.4 & 0.9 & 0.9 \\
\cline { 2 - 10 } & standard deviation & 37.2 & 1547.3 & 9.7 & 2.2 & 4.0 & 0.3 & 0.1 \\
\hline
\end{tabular}

\begin{tabular}{|l||c|c|c|c|c|c|c|}
\hline Year & Indicator - nitric acid & $\mathbf{C o}$ & $\mathbf{N i}$ & $\mathbf{C r}$ & $\mathbf{P b}$ & $\mathbf{C d}$ & $\mathbf{H g}$ \\
\hline \hline \multirow{2}{*}{ Autumn 2009 } & average & 13.3 & 26.3 & 33.1 & 20.8 & 0.8 & 0.3 \\
\cline { 2 - 9 } & standard deviation & 0.7 & 1.3 & 3.0 & 1.6 & 0.1 & 0.3 \\
\hline \multirow{2}{*}{ Spring 2010 } & average & 13.7 & 27.5 & 29.3 & 17.8 & 1.3 & 0.3 \\
\cline { 2 - 9 } & standard deviation & 1.3 & 1.8 & 1.9 & 1.4 & 0.2 & 0.6 \\
\hline \multirow{2}{*}{ Autumn 2010 } & average & 14.7 & 28.6 & 30.7 & 18.0 & 1.1 & 0.1 \\
\cline { 2 - 9 } & standard deviation & 0.7 & 1.4 & 2.6 & 1.3 & 0.1 & 0.1 \\
\hline
\end{tabular}


Habovštiak and Daniel (2001) indicate that in the production year, an average yield of 12.0 to 15.0 t.ha $^{-1}$ dry matter is probable. With this statement we can only agree with ULV variety, since its yield was higher than $12.0 \mathrm{t}$ of dry matter.ha-1 $\mathrm{yr}^{-1}$ (plant spacing A: 12.46 t.ha $^{-1} \cdot \mathrm{yr}^{-1}$ and plant spacing B: 13.80 t.ha $^{-1}$.yr $r^{-1}$ ).

Summary results of laboratory analysis according to the methodology approved in the project solved between $1^{\text {st }}$ September, 2009 to $31^{\text {st }}$ December, 2011, in sampled and analysed above-ground biomass of common osier willow (Salix viminalis L.) fertilized by analysed wood ash are given in Table 2. The whole results of the analysis taken under the canopy of common osier willow fertilized by analysed wood ash are summarized in Table 3. In both cases, the year 2009 refers to the input value of the indicator, and the year 2010 represents the change of the parameter after the autumn and the spring application of wood ash.

Wood ash obtained from a bottom area of the boiler after burning of biomass originated from the burning of clean and chemically untreated wood from the thermal CHP power plant in Hriňová. Content of hazardous elements in the applied wood ash ( $\mathrm{As}, \mathrm{Cd}, \mathrm{Cr}, \mathrm{Hg}, \mathrm{Pb}$ ) was lower than limit values of risk mineral elements of calcium and magnesium-calcium fertilizer under the Ministry of Agriculture Regulation from 15. 12. 2000, stipulating the types of fertilizers, the content of risk elements, conditions of sampling and methods for testing fertilizers, Coll. of Laws 26/2001, Supplement No. 2, content and other elements considered to be risky in the raw material for compost $(\mathrm{Cu}$, Mo, Ni, Zn) was lower than the limit values of risk elements in raw materials for composting, according to STN 465735 "Industrial composts". Wood ash contained $11.5 \%$ calcium, $4.0 \%$ potassium and $1.4 \%$ magnesium.

The samples of the contents of the selected components and parameters during the monitoring of properties of crop material common osier willow (Salix viminalis L.) were evaluated before application of wood ash on the habitat in the autumn. Significant changes of total nitrogen- $\mathrm{N}$ were not shown so far, on the contrary, its content decreased because wood ash is not one of the nitrogenous fertilizers. The results of complex agroclimatic effects were changes in different forms of nitrogen in the soil. It is recommended to get nitrogen into soil with other fertilizers or soil additive substances, for example application of bio sediments, irrigation by pre-cleaned waste water, etc. We have not found fertilizing energy crops with nitrogen in practice. In the other measured indicators there was no significant change, that means the wood ash has minimum (negative) effect on soil chemical properties. The biggest recorded change is an increased content of potassium which has a positive impact on increasing resistance of plants and probably caused reduction of sodium content in some samples. The content of manganese was slightly increased as well. The content of most studied heavy metals in the biomass was either at the same level or its content decreased (for example $\mathrm{Co}, \mathrm{Ni}, \mathrm{Cr}$, $\mathrm{Pb}, \mathrm{Cd}$ ) as a cause of fertilizing with wood ash.

Samples of the contents of selected components and parameters during the monitoring of soil characteristics under the canopy of basket willow (Salix Viminalis L.) were evaluated before each application of wood ash on the habitat in the spring and the autumn, according to the approved methodology. Significant changes of total nitrogen - $N_{t}$ causing fertilizing by wood ash were not shown so far because wood ash is not one of the nitrogenous fertilizers. Changes related in different forms of $\mathrm{N}$ contents in soil are result of complex agro- climatic impacts on soil, particularly its microbial activity. In the other measured indicators, in terms of sequences of takings, there were not shown significant changes, it means that the wood ash has minimum (negative) effect on soil chemical properties. Just a small increase of heavy metals- $\mathrm{Co}, \mathrm{Ni}, \mathrm{Cd}$ was recorded when the both solvents were used. For the other heavy metals there was constant or even decreased content $(\mathrm{Cu}$, $\mathrm{Cr}, \mathrm{Pb})$.

After studying available published domestic and foreign literature in similar issues as well as the results of the project, there can be the conclusion that wood ash with matching parameters and with stable properties, applied according to standard methodologies, has no direct negative impact on the soil and crop harvested for non-food use. On the contrary, in many cases and in some elements it came to the reduction of undesirable substances in the soil and the plant, as well as to the increase in the production of dry organic matter of grown crops. These facts are properly documented in the literature and in the tables attached to this document. Certain technical issues, especially stabilizing properties of wood ash as well as its applicability need to be resolved according to the other projects, examples and experiences. Another problem in the case of application of wood ash is the lack of unchecked nitrogen content in the soil and cultivated plants because wood ash contains only negligible quantities of N. However, this may be the subject to further legislative measures and projects. Based on the facts, we proposed the formal legislative way to allow the application of wood ash for fertilization of forest and agricultural land, for agricultural crops this could be performed just for agricultural land that has no long cultivated crops for non-food use. The wood ash can be used only from combustion of mechanically treated wood or wood waste. Used wood ash can contain maximum levels of chosen heavy metals, which are listed in the Table 3. Analysis of wood ash in the content of heavy metals must be made in the delivery of wood ash before each cycle of an application.

Based on the results of the project as well as studying the available literature we suggest the maximum dose of wood ash at 3.0 t. ha-1 of dry matter. Each application cycle within the same land should be realized in four-year intervals, after harvest. Keeping this procedure, the risk associated with the application of wood ash as a fertilizer is minimized by almost $100 \%$.

\section{Conclusions}

Fast growing basket willow - common osier (Salix viminalis L.) has been grown on experimental base in Dolná Malanta, Nitra, Slovakia since 1996. In 12 years of its cultivation, the crop has been retained in a condition suitable for energetic, but also for therapeutic purposes and creates conditions for further observation and assessment in future. By experiment, the influence of factors on aboveground biomass production was studied: variety (ORM, 
RAPP, ULV), design of crop organization (method A - double rows $=0.5 \mathrm{~m} \times 0.75 \mathrm{~m}$ or $1.25 \mathrm{~m}$; method $\mathrm{B}=0.5 \mathrm{~m} \times 0.75 \mathrm{~m}$ ) and the impact of crop years (2008-2011). From dried and weighted samples of plant rods following conclusions can be drawn. In the $6^{\text {th }}$ year of cultivation, the height of vegetation ranged from $3.34 \mathrm{~m}$ (RAPP/B) to $4.27 \mathrm{~m}$ (ULV/B). The highest average height of vegetation was in variety ULV $4.23 \mathrm{~m}$, followed by ORM $4.01 \mathrm{~m}$ and the lowest height was recorded in a variety RAPP $3.48 \mathrm{~m}$. The average thickness of plant rods ranged from $13.2 \mathrm{~mm}$ RAPP/B to $18.2 \mathrm{~mm}$ ULV/B. Yield of the third harvest period measured in dry matter varied in significantly wide range: from 16.7 (RAPP/A) to 55.2 t.ha $^{-1}$ (ULV/B). Based on measured and calculated data the varieties of willow can be ordered according to their suitability for the conditions of southern Slovakia as follows: 1. ULV $\left(52.5\right.$ t.ha $\left.^{-1}\right)$; 2. ORM $\left(41.3\right.$ t.ha $\left.^{-1}\right)$; 3. RAPP $\left(24.3\right.$ t.ha $\left.^{-1}\right)$. In terms of planting organization, better results were achieved in planting space $B\left(41.8\right.$ t.ha $\left.^{-1}\right)$ than in planting space $A$ (36.9 t.ha- ${ }^{-1}$ ).

The result of the project "Efficiency of fertilization potential of wood-ash for energy plants cultivation as renewable energy resources (Ash as fertilizer)" will be the determination of an appropriate procedure in application of wood ash for the intensification of energetic plants cultivation. Since, in accordance with the Slovak Republic legislation, it is allowed to use wood ash only for the scientific purposes, we assume that the results obtained in this project will be applied in the modification of legislative framework to enable the use of wood ash for applying nutrients in energy plants cultivation.

The aim of the project is to establish an appropriate procedure for the application of wood ash for intensification of cultivation of energy crops on forest and arable land for non-food use. Because Slovakia, in accordance with current legislation can use wood ash as a fertilizer only in research, we consider that the results obtained not only in this project but also with similarly oriented projects in Slovakia as well as examples of international studies will find application to change the legislative framework and the subsequent use of wood ash as a substitute for the nutrients in the cultivation of energy plants in the term of following power in Slovakia.

\section{Acknowledgement}

The work is carried out through funding by Ministry of Education, Science, Research and Sport of the Slovak Republic under the Project VEGA No.: 1/0942/12: "Variety dependence of production and energetic potential of fast growing woody plants of genus Salix and Populus in the first and second three-years harvest cycles and energetic grass Miscanthus in agro-climatic conditions of Southwestern Slovakia" and project APVV VMSP-P-0035-09..

\section{References}

ČIMO, J. - ŠPÁNIK, F. 2009. The agro climatic analysis phytomass production of Salix (Salix Vilimalis). In: Sustainable development and bioclimate, Stará Lesná. Bratislava : Slovenská bioklimatologická spoločnost', 2009. pp. 142-143. ISBN 978-80-900450-1-9.

HABOVŠTIAK, J. - DANIEL, J. 2001. Pestovanie odrôd vŕby (Salix viminalis) na energetické účely. In: Naše pole, 2001, č. 5, s. 10. ISSN 1335-2466.

HÚSKA, J. et al. 2000. Experimentálne výsledky z pestovania vŕby košikárskej (Salix viminalis). In: Nová energetická politika SR: obnovitel'né zdroje energie, aproximácia k politike EÚ (zborník z medzinárodnej konferencie). Bratislava : Dadaexpress, 2000. s. 124-128. ISBN 80-968421-0-2.

JAMRIŠKA, P. 2001. Rastliny na nepotravinárske využívanie. Nitra : SPU, 2001.69 s. ISBN 80-7137-877-1.

MAGA, J. - NOZDROVICKÝ, L. - PEPICH, Š. - MARHAVÝ, Ł. - HAJDU, Š. 2008. Komplexný model využitia biomasy na energetické účely. Nitra : SPU, 2008. 183 s. ISBN 978-80-552-0029-3.

NIŇAJ, M. - HÚSKA, J. 2005. Vúba - zdroj energie. In: Úroda, 2005, č. 6, s. 38-39. ISSN 0139-6013.

OTEPKA, P. - HABÁN, M. 2006. Biomass yield of basket willow (Salix viminalis L.) cultivated as energy plant in a long-term experiment. In: Acta fytotechnica et zootechnica, vol. 9, 2006, no. 3, pp. 70-74. ISSN 1335-258X.

OTEPKA, P. - HABÁN, M. 2011. Vŕba košikárska (Salix viminalis L.) pestovaná ako obnovitel'ný zdroj energie $v$ teplej agroklimatickej makrooblasti Slovenskej republiky. Nitra : SPU, $83 \mathrm{~s}$. ISBN 978-80-552-0660-8.

HABÁN, M. - OTEPKA, P. - BOROŠ, J. 2013. Produkcia biomasy vŕby košikárskej na ene energetické účely na Slovensku a vo Švédsku. Nitra : SPU, 92 s. ISBN 978-80-552-1006-3.

\section{Contact address:}

Pavol Otepka, Slovak University of Agriculture in Nitra, Faculty of European Studies and Regional Development, Department of Sustainable Development, Tr. A. Hlinku 2, 94976 Nitra, Slovakia, e-mail: Pavol.Otepka@uniag.sk 